\title{
SEASONAL DISTRIBUTION OF MALARIA VECTORS (DIPTERA: CULICIDAE) IN RURAL LOCALITIES OF PORTO VELHO, RONDÔNIA, BRAZILIAN AMAZON
}

\author{
Luiz Herman Soares GIL, Moreno de Souza RODRIGUES, Alzemar Alves de LIMA \& Tony Hiroshi KATSURAGAWA
}

\begin{abstract}
SUMMARY
We conducted a survey of the malaria vectors in an area where a power line had been constructed, between the municipalities of Porto Velho and Rio Branco, in the states of Rondônia and Acre, respectively. The present paper relates to the results of the survey of Anopheles fauna conducted in the state of Rondônia. Mosquito field collections were performed in six villages along the federal highway BR 364 in the municipality of Porto Velho, namely Porto Velho, Jaci Paraná, Mutum Paraná, Vila Abunã, Vista Alegre do Abunã, and Extrema. Mosquito captures were performed at three distinct sites in each locality during the months of February, July, and October 2011 using a protected human-landing catch method; outdoor and indoor captures were conducted simultaneously at each site for six hours. In the six sampled areas, we captured 2,185 mosquitoes belonging to seven Anopheles species. Of these specimens, 95.1\% consisted of Anopheles darlingi, 1.8\% An. triannulatus 1.s., 1.7\% An. deaneorum, $0.8 \%$ An. konderi 1.s., 0.4 An. braziliensis, $0.1 \%$ An. albitarsis $1 . s$., and $0.1 \%$ An. benarrochi. An. darlingi was the only species found in all localities; the remaining species occurred in sites with specific characteristics.
\end{abstract}

KEYWORDS: Anopheles; Rondônia; HBR; Hydroelectric power plant.

\section{INTRODUCTION}

Although cases of malaria have decreased in Brazil since 2005, the disease remains an important public health problem in the country. In 2012 alone, approximately 240,000 cases were recorded here, of which more than $90 \%$ occurred in the Amazon region ${ }^{3}$.

Anopheline mosquitoes are the only vectors of Plasmodium spp. parasites to humans. These mosquitoes are found in tropical and neotropical regions. As of 2004, 476 species had been recorded ${ }^{26}$, of which approximately 100 are considered vectors or potential vectors of Plasmodium spp. to humans ${ }^{22,38}$. In the Amazon region, the main disease vector is Anopheles darlingi, although other species such as An. deaneorum, An. triannulatus, and An. nuneztovari may play important roles in the epidemiology of the disease ${ }^{35,36,43}$. The occurrence of an anopheline species in an endemic area is associated with the environmental characteristics of the region.

South America is currently among the regions most affected by environmental changes, mainly because of the great pressure caused by humans in the area. The construction of hydroelectric power plants, family farming, and selective logging, among many other activities, has become common in the region ${ }^{44}$. The changes caused by these activities can drastically influence the population dynamics of malaria vectors, thereby increasing malaria cases in the region. Thus, the assessment of mosquito population density and species occurrence in areas where these activities take place or will take place is essential for evaluating the risk of malaria transmission and for designing and implementing effective measures of control and/or prevention.

Therefore, our study aimed to assess the changes in the number and composition of anopheline species along the construction corridor of a power transmission line.

\section{MATERIALS AND METHODS}

Mosquito capture was conducted along a $380 \mathrm{~km}$ stretch of the BR 364 highway, between Porto Velho (RO) and Rio Branco (AC). Six distinct localities with the highest population densities along the stretch were selected. These localities were Extrema (0945'29.1"S 66 21'34.3"W), Vista Alegre (09³9'39.8"S 6543'57.2"W), Abunã (0941'48.9"S 65²2'15.8"W), Mutum Paraná (09³7'01.3"S $\left.64^{\circ} 56^{\prime} 24.4^{\prime \prime W}\right)$, Jaci Paraná $\left(09^{\circ} 15^{\prime} 37.2^{\prime \prime S} 64^{\circ} 23^{\prime} 44.1^{\prime \prime W}\right)$, and Porto Velho $\left(08^{\circ} 48^{\prime} 35.5^{\prime \prime S} 63^{\circ} 56^{\prime} 30.3^{\prime \prime W}\right)$ (Fig. 1). Vegetation in these areas predominantly consists of open rain forest with a high degree of human disturbance, as evidenced by the removal of native vegetation and its replacement by pasture. 
GIL, L.H.S.; RODRIGUES M.S.; LIMA, A.A. \& KATSURAGAWA, T.H. - Seasonal distribution of malaria vectors (Diptera: Culicidae) in rural localities of Porto Velho, Rondônia, Brazilian Amazon. Rev. Inst. Med. Trop. Sao Paulo, 57(3): 263-7, 2015.

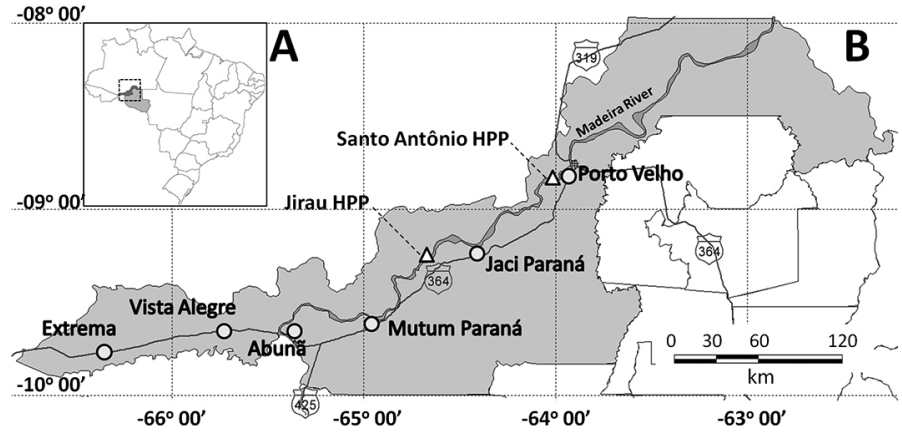

Fig. 1 - Locations of capture sites. (A) State of Rondônia location in Brazil. (B) Magnified view of Porto Velho municipality and localities of anopheline mosquito capture sites (circles) and hydroelectric power plants (triangle) location.

Captures were performed at three sites in each locality during the months of February, July, and October 2011. Three dwellings were selected at each site, and protected human landing catches were performed simultaneously inside and outside of each dwelling. The collection sites remained the same throughout the whole study for posterior comparison. Mosquitoes were stored in plastic cups and identified using dichotomous keys for females ${ }^{6,13}$. The species compositions of the distinct areas were compared using PERMANOVA, followed by PERMDISP and scored on NMDS. For these analyses, the vegan package was used in $\mathrm{R}^{37}$. The comparison of An. darlingi density among localities and between indoor and outdoor dwellings was performed using ANOVA, and the negative binomial error distribution was adjusted to correct overdispersion problems. All analyses were performed at a significance level of $5 \%$.

\section{RESULTS}

We collected 2,185 anopheline mosquitoes belonging to seven species in the six localities. Of the mosquitoes collected, $95.1 \%$ were identified as An. darlingi, $1.8 \%$ as An. triannulatus 1.s., $1.7 \%$ as $A n$. deaneorum, $0.8 \%$ as An. konderi 1. s., $0.4 \%$ as An. braziliensis, $0.1 \%$ as An. albitarsis 1.s., and $0.1 \%$ as An. benarrochi 1.s. Anopheles darlingi was collected in all localities. The remaining species were found in sites with unique characteristics (e.g., An. braziliensis was predominantly found in areas of secondary growth, such as forest clearings and pastures) (Table 1). Mutum Paraná, Porto Velho, and Jaci Paraná exhibited four of the seven collected species, whereas only two were found in Extrema, Vista Alegre do Abunã, and Vila Abunã. Moreover, although these areas had the same number of species, their species composition (i.e., species found in the area) significantly differed (PERMANOVA S.S = 1.37; Pseudo- $F<0.001$ ). However, no significant differences in Anopheles spp. community homogeneity were observed among the study areas (Permdisp $p=0.34$; Fig. 2). Analysis of the distribution patterns of the main malaria vectors showed that the number of An. darlingi differed significantly among localities (ANOVA $\chi^{2}=$ $44.35, p<0.001$ ), with Porto Velho exhibiting the highest mean number of individuals of this species (144.55 \pm 59.81$)$ and Vila Abunã exhibiting the lowest $(5.66 \pm 1.04)$. The mean distribution of An. darlingi among the localities is summarized in Table 2. With the exception of Vista Alegre do Abunã, An. darlingi numbers were significantly higher in outdoor than indoor dwellings (ANOVA $\chi^{2}=27.79, p<0.001$; Fig. 3).
Table 1

Number and distribution of collected mosquitoes

\begin{tabular}{lccc}
\hline Species & Total & Frequency & Area \\
\hline Anopheles albitarsis 1.s. & 2 & 0.09 & AB; MP \\
Anopheles benarrochi & 2 & 0.09 & JP \\
Anopheles braziliensis & 8 & 0.37 & MP; PVH \\
Anopheles darlingi & 2,078 & 95.10 & PVH; EX; VA; \\
Anopheles deaneorum & 38 & 1.74 & AB; MP; JP \\
Anopheles konderi 1.s. & 17 & 0.78 & JP; PVH \\
Anopheles triannulatus 1.s. & 40 & 1.83 & PVH; JP; MP \\
\hline
\end{tabular}

$\mathrm{AB}=$ Abunã; $\mathrm{EX}=$ Extrema; JP = Jaci Paraná; $\mathrm{MP}=$ Mutum Paraná; $\mathrm{PVH}=$ Porto Velho; VA = Vista Alegre Abunã.

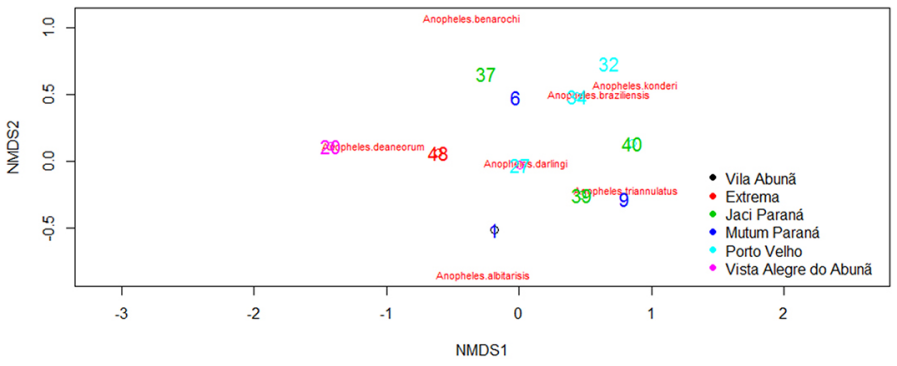

Fig. 2 - Scoring of the areas according to the composition of anopheline species.

Table 2

Number and distribution of Anopheles darlingi mosquitoes collected by locality

\begin{tabular}{lccc}
\hline Locality & Mean \pm SD & $\begin{array}{c}\text { Contrast } \\
\text { analysis }\end{array}$ & $p$ value \\
\hline Porto Velho & $144.55 \pm 59.81$ & $\mathrm{a}$ & $<0.001$ \\
\hline Jaci Paraná & $37.22 \pm 10.40$ & $\mathrm{~b}$ & \\
Extrema & $26.55 \pm 12.27$ & $\mathrm{~b}$ & 0.30 \\
Mutum Paraná & $23.77 \pm 2.78$ & $\mathrm{~b}$ & \\
Vila Abunã & $7.11 \pm 1.04$ & $\mathrm{c}$ & \\
Vista Alegre do Abunã & $5.66 \pm 2.71$ & $\mathrm{c}$ & 0.63 \\
\hline
\end{tabular}

SD: standard deviance; columns followed by different letters indicate statistical difference.
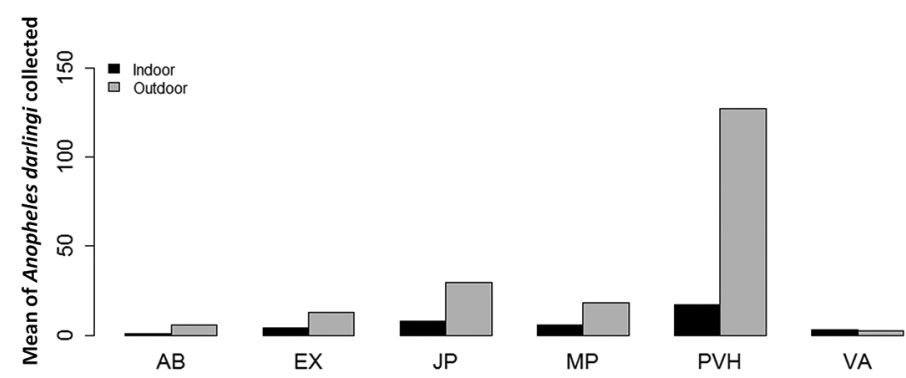

Fig. 3 - Mean of Anopheles darlingi collected per night in and around dwellings of various localities under study. $\mathrm{AB}=$ Abunã $\mathrm{EX}=$ Extrema; JP = Jaci Paraná; $\mathrm{MP}=$ Mutum Paraná; $\mathrm{PVH}=$ Porto Velho; $\mathrm{VA}=$ Vista Alegre Abunã. 


\section{DISCUSSION}

In Brazil, six species of anopheline mosquitoes play significant roles in the transmission of Plasmodium spp. parasites to humans. Three of these species were collected in our study: An. darlingi, An. triannulatus, and An. braziliensis. Other species such as An. albitarsis 1.s. may be secondary or specific vectors in particular areas ${ }^{29,35,36,43}$. The prevalence of An. darlingi has remained consistently higher than that of other species since the first studies of malaria vectors in Rondônia, even amid the environmental changes that have taken place over the last few decades $5,7,10,11,12,16,17,18,32$. The high prevalence of Anopheles darlingi in this study was expected, as this species presents the most anthropophilic behavior among the sample collected. Furthermore, many of the environmental changes in this region (e.g., flooding of areas and the creation of water reservoirs for human use) have increased the number of breeding sites for this species ${ }^{33}$.

The peak number of species occurred in July. Anopheles darlingi showed two distinct population peaks, the first in March/May (during the rainy season) and the second in August/September (end of the dry season $)^{18}$. The peak in July may be explained by the environmental changes in the area due to the implementation of two hydroelectric power plants, or a delay in the response of An. darlingi to the rainy season.

The susceptibility of anopheline mosquitoes to infection by the predominant Plasmodium species recorded in the region, $P$. falciparum and $P$. vivax, has been previously reported ${ }^{9,27,28,31}$. Although the highest number of mosquitoes occurred around dwellings, the results highlight that An. darlingi exhibits highly anthropophilic behavior. Moreover, although we did not find a higher number of mosquitoes inside dwellings, these species are highly endophilic ${ }^{15,21,30}$, making the study region a highrisk area for the transmission and prevalence of malaria.

New farming frontiers in areas where malaria is endemic require more public policies for mosquito control ${ }^{8,34,41}$. Climate change, urbanization, and new settlements for agriculture and the rearing of livestock are among the factors that can lead to epidemics of malaria and other vector-borne diseases $^{41}$.

As the localities of the present study are situated within the area of influence of two hydroelectric power plants in the Madeira River, with intense anthropization and increased water surface, and the results obtained indicate high vector densities in urbanized areas, the current malaria situation requires attention. The Madeira River carries a large quantity of suspended sediment, which favors the predominance of mosquitoes of the Mansonia genus. The river water does not exhibit this characteristic, however, the conditions in this water promote the proliferation of An. darling $i^{39}$. Therefore, despite the decreased number of malaria cases over the last few years in $\mathrm{Brazil}^{3}$, urban expansion in the proximity of these new water reservoirs increases the risk of malaria transmission ${ }^{14,40}$.

Factors such as the creation of water reservoirs and deforestation caused by the construction of hydroelectric power plants and power lines, as well as peri-urban transmission of disease ${ }^{18,42}$, have increased the density of malaria vectors ${ }^{1,2,4,5,23,24,25}$, thereby elevating the risk of epidemics within the next several decades ${ }^{19,20}$.
Because anopheline mosquitoes are key determinants in the transmission of Plasmodium, which can infect and cause malaria in humans, the regular monitoring of the disease transmission of these vectors in relation to regional climate cycles is of paramount importance. Moreover, scientifically-based joint and coordinated action between public authorities and construction entrepreneurs should be conducted to control malaria transmission in the Brazilian Amazon.

\section{RESUMO}

\section{Distribuição sazonal de vetores da malária (Diptera: Culicidae) em localidades rurais de Porto Velho, Rondônia, Amazônia brasileira}

Foi realizado levantamento de vetores de malária na área que compreende a construção da linha de transmissão entre os municípios de Porto Velho e Rio Branco, estados de Rondônia e Acre, respectivamente. Os dados aqui apresentados mostram os resultados do levantamento da fauna dos Anopheles realizado em Rondônia. As capturas foram realizadas no município de Porto Velho em seis aglomerados populacionais ao longo da rodovia federal BR 364, denominados Porto Velho, Jaci Paraná, Mutum Paraná, Vila Abunã, Vista Alegre do Abunã e Extrema. As capturas ocorreram em três diferentes pontos de cada uma das localidades nos meses de fevereiro, julho e outubro de 2011, seguindo a metodologia de coleta por atração humana protegida em dois ambientes, sendo no intradomicílio e no peridomicílio simultaneamente com duração de seis horas. Nas áreas amostradas foram capturados 2.185 anofelinos pertencentes a sete espécies de Anopheles sp. dos quais 95,1\% foram identificados como Anophels darlingi, 1,8\% An. triannulatus 1.s., 1,7\% An. deaneorum, 0,8\% An. konderi 1.s., 0,4 An. braziliensis, 0,1\% An. albitarsis 1.s., e 0,1\% An. benarrochi. Anopheles darlingi foi a única espécie amostrada em todas as localidades enquanto as demais espécies, ocorreram em locais com características singulares.

\section{FINANCIAL SUPPORT}

This study received financial and logistical support from Cepemar Serviços de Consultoria em Meio Ambiente Ltda.

\section{REFERENCES}

1. Alves FP, Durlacher RR, Menezes MJ, Krieger H, Silva LH, Camargo EP. High prevalence of asymptomatic Plasmodium vivax and Plasmodium falciparum infections in native Amazonian populations. Am J Trop Med Hyg. 2002;66:641-8.

2. Alves FP, Gil LH, Marrelli MT, Ribolla PE, Camargo EP, da Silva LH. Asymptomatic carriers of Plasmodium spp. as infection source for malaria vector mosquitoes in the Brazilian Amazon. J Med Entomol. 2005;42:777-9.

3. Brasil. Ministério da Saúde. Secretaria de Vigilância Epidemiológica. Sistema de Informação de Vigilância Epidemiológica-SIVEP-Malária. [cited 15 Sep 2013]. Available from: http://www.saude.gov.br/sivep_malaria

4. Camargo EP, Alves F, Pereira da Silva LH. Symptomless Plasmodium vivax infections in native Amazonians. Lancet. 1999;353:1415-6.

5. Camargo LM, Noronha E, Salcedo JM, Dutra AP, Krieger H, Pereira da Silva LH, et al The epidemiology of malaria in Rondonia (Western Amazon region, Brazil): study of a riverine population. Acta Trop. 1999;72:1-11. 


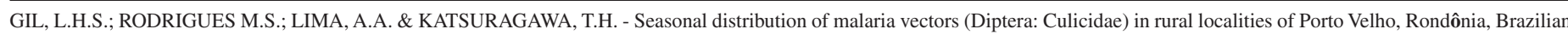
Amazon. Rev. Inst. Med. Trop. Sao Paulo, 57(3): 263-7, 2015.

6. Consoli RA, Oliveira RL. Principais mosquitos de importância sanitária no Brasil. Rio de Janeiro; Fiocruz; 1994.

7. Cruz RM, Gil LH, de Almeida e Silva A, da Silva Araújo M, Katsuragawa TH. Mosquito abundance and behavior in the influence area of the hydroelectric complex on the Madeira River, Western Amazon, Brazil. Trans R Soc Trop Med Hyg. 2009;103:11746.

8. de Castro MC, Monte-Mór RL, Sawyer DO, Singer BH. Malaria risk on the Amazon frontier. Proc Natl Acad Sci. 2006;103:2452-7.

9. de Oliveira-Ferreira J, Lourenço-de-Oliveira R, Teva A, Deane LM, Daniel-Ribeiro CT. Natural malaria infections in anophelines in Rondonia State, Brazilian Amazon. Am J Trop Med Hyg. 1990;43:6-10.

10. Deane LM. Malaria vectors in Brazil. Mem Inst Oswaldo Cruz. 1986;81(Suppl 2):5-14.

11. Deane LM, Causey CR, Deane MP. Notas sobre a distribuição e a biologia dos anofelinos das regiões nordestina e amazônica do Brasil. Rev Serv Espec Saúde Pública. 1948;1:827-965.

12. Deane LM, Daniel Ribeiro C, Lourenço de Oliveira R, Oliveira-Ferreira J, Guimarães AE. Study on the natural history of malaria in areas of the Rondonia State-Brazil and problems related to its control. Rev Inst Med Trop Sao Paulo. 1988;30:153-6.

13. Forattini OP. Culicidologia médica: identificação, biologia, epidemiologia. São Paulo; EDUSP; 2002.

14. Freitas FT, Costa CM, Nóbrega AA, Araújo WN. Surto de malária no distrito de JaciParaná, município de Porto Velho-RO, em 2009. Bol Epidemiol Eletron. 2010;10:1-4.

15. Gama RA. Periodicidade de hematofagia de Anopheles darlingi, em Porto Velho (RO), e modificação da armadilha BG-Sentinel® para a captura de anofelinos, visando à substituição da atração humana. [PhD thesis]. Belo Horizonte: Universidade Federal de Minas Gerais, Instituto de Ciências Biológicas; 2009.

16. Gama RA, Silva IM, Monteiro HA, Eiras AE. Fauna of Culicidae in rural areas of Porto Velho and the first record of Mansonia (Mansonia) flaveola (Coquillet, 1906), for the state of Rondônia, Brazil. Rev Soc Bras Med Trop. 2012;45:125-7.

17. Gil LH, Alves FP, Zieler H, Salcedo JM, Durlacher RR, Cunha RP, et al. Seasonal malaria transmission and variation of anopheline density in two distinct endemic areas in Brazilian Amazonia. J Med Entomol. 2003;40:636-41.

18. Gil LH, Tada MS, Katsuragawa TH, Ribolla PEM, Pereira da Silva LH. Urban and suburban malaria in Rondônia (Brazilian Western Amazon). II. Perennial transmissions with high anopheline densities are associated with human environmental changes. Mem Inst Oswaldo Cruz. 2007;102:271-6.

19. Gomes AC, Paula MB, Duarte AM, Lima MA, Malafronte RS, Mucci LF, et al. Epidemiological and ecological aspects related to malaria in the area of influence of the lake at Porto Primavera dam, in western São Paulo State, Brazil. Rev Inst Med Trop São Paulo. 2008;50:287-95.

20. Gomes AC, Paula MB, Natal D, Gotlieb SL. Ecologia de Anopheles (Nyssorhynchus) darlingi Root em área de implantação de empreendimento hidrelétrico, na divisa dos estados de Mato Grosso do Sul e São Paulo. Rev Soc Bras Med Trop. 2010;43:272-6.

21. Guimarães AE, Gentile C, Lopes CM, de Mello RP. Ecology of mosquitoes (Diptera: Culicidae) in areas of Serra do Mar State Park, State of São Paulo, Brazil. III. Daily biting rhythms and lunar cycle influence. Mem Inst Oswaldo Cruz. 2000;95:753-60.

22. Harbach RE. The classification of genus Anopheles (Diptera: Culicidae): a working hypothesis of phylogenetic relationships. Bull Entomol Res. 2004;94:537-53.

23. Katsuragawa TH, Cunha RP, de Souza DC, Gil LH, Cruz RB, Silva AA, et al. Malária e aspectos hematológicos em moradores da área de influência dos futuros reservatórios das hidrelétricas de Santo Antônio e Jirau, Rondônia, Brasil. Cad Saúde Pública. 2009;25:1486-92.
24. Katsuragawa TH, Gil LH, Tada MS, Pereira da Silva LH. Endemias e epidemias na Amazônia. Malária e doenças emergentes em áreas ribeirinhas do Rio Madeira. Um caso de escola. Estudos Av. 2008;22:111-41.

25. Katsuragawa TH, Gil LH, Tada MS, de Almeida e Silva A, Costa JDN, Araújo MS, et al The dynamics of transmission and spatial distribution of malaria in riverside areas of Porto Velho, Rondônia, in Amazon Region of Brazil. PLOS One. 2010;5:e9245.

26. Kiszewski A, Mellinger A, Spielman A, Malaney P, Sachs SE, Sachs J. A global index representing the stability of malaria transmission. Am J Trop Med Hyg. 2004;70:48698.

27. Klein TA, Lima JB, Tada MS, Miller R. Comparative susceptibility of anopheline mosquitoes in Rondonia, Brazil to infection by Plasmodium vivax. Am J Trop Med Hyg. 1991;45:463-70.

28. Klein TA, Lima JB, Tada MS. Comparative susceptibility of anopheline mosquitoes to Plasmodium falciparum in Rondonia, Brazil. Am J Trop Med Hyg. 1991;44:598-603.

29. Laporta GZ, Ramos DG, Ribeiro MC, Sallum MAM. Habitat suitability of Anopheles vector species and association with human malaria in the Atlantic Forest in southeastern Brazil. Mem Inst Oswaldo Cruz. 2011;106(Suppl 1):239-45.

30. León W, Valle J, Naupay R, Tineo E, Rosas A, Palomino M. Comportamiento estacional del Anopheles (Nyssorhynchus) darlingi Root 1962 en localidades de Loreto y Madre de Dios, Peru 1999-2000. Rev Peru Med Exp Salud Publica. 2003;20:22-7.

31. Marrelli MT, Honório NA, Flores-Mendoza C, Lourenço-de-Oliveira R, Marinotti O, Kloetzel JK. Comparative susceptibility of two members of the Anopheles oswaldoi complex, An. oswaldoi and An. konderi, to infection by Plasmodium vivax. Trans $\mathrm{R}$ Soc Trop Med Hyg. 1999;93:381-4.

32. Morais SA, Urbinatti PR, Sallum MA, Kuniy AA, Moresco GG, Fernandes A, et al Brazilian mosquito (Diptera: Culicidae) fauna. I. Anopheles species from Porto Velho, Rondônia State, western Amazon, Brazil. Rev Inst Med Trop Sao Paulo. 2012;54:331-5.

33. Moutinho PR, Gil LH, Cruz RB, Ribolla PE. Population dynamics, structure and behavior of Anopheles darlingi in a rural settlement in the Amazon rainforest of Acre, Brazil. Malar J. 2011;10:174.

34. Natal D, Barata JM, Lagos CB, Rocha RM. Nota sobre culicídeos (Diptera: Culicidae) da bacia do rio Purus, Acre, Amazônia (Brasil). Rev Saúde Pública. 1992;26:129-31.

35. Póvoa MM, Conn JE, Schlichting CD, Amaral JC, Segura MN, Da Silva AN, et al. Malaria vectors, epidemiology, and the re-emergence of Anopheles darlingi in Belém, Pará, Brazil. J Med Entomol. 2003;40:379-86.

36. Póvoa MM, de Souza RT, Lacerda RN, Rosa ES, Galiza D, de Souza JR, et al. The importance of Anopheles albitarsis $\mathrm{E}$ and An. darlingi in human malaria transmission in Boa Vista, state of Roraima, Brazil. Mem Inst Oswaldo Cruz. 2006;101:163-8.

37. R Development Core Team. R: a Language and Environment for Statistical Computing. Vienna: R Development Core Team; 2014. Available from: http://www.r-project.org

38. Raghavendra K, Barik TK, Reddy BP, Sharma P, Dash AP. Malaria vector control: from past to future. Parasitol Res. 2011;108:757-79.

39. Rodrigues IB, Tadei WP, Dias JM, Lima CA. Atividade larvicida de Bacillus sphaericus 2362 contra Anopheles sp. (Diptera, Culicidae) em rios do Amazonas, Brasil. BioAssay. 2013;8:2. [cited 15 Jan 2014]. Available from: http://www.bioassay.org. br/bioassay/article/download/95/178

40. Saraiva MD, Amorim RD, Moura MA, Martinez-Espinosa FE, Barbosa MD. Expansão urbana e distribuição espacial da malária no município de Manaus, Estado do Amazonas. Rev Soc Bras Med Trop. 2009;42:515-22.

41. Sutherst RW. Global change and human vulnerability to vector-borne diseases. Clin Microbiol Rev. 2004;17:136-73. 


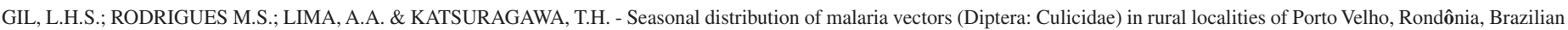
Amazon. Rev. Inst. Med. Trop. Sao Paulo, 57(3): 263-7, 2015.

42. Tada MS, Marques PR, Mesquita E, Dalla-Martha RC, Rodrigues AJ, Costa JDN, et al. Urban malaria in the Brazilian Western Amazon Region. I. High prevalence of asymptomatic carriers in an urban riverside district is associated with a high level of clinical malaria. Mem Inst Oswaldo Cruz. 2007;102:263-9.

43. Tadei WP, Dutary Thatcher B. Malaria vectors in the Brazilian Amazon: Anopheles of the subgenus Nyssorhynchus. Rev Inst Med Trop Sao Paulo. 2000;42:87-94.

44. Tadei WP, Thatcher BD, Santos JM, Scarpassa VM, Rodrigues IB, Rafael MS. Ecologic observations on anopheline vectors of malaria in the Brazilian Amazon. Am J Trop Med Hyg. 1998;59:325-35

Received: 26 March 2014

Accepted: 30 September 2014 